\title{
The Salsigne Gold Mine: A World-Class Ore Body in the South West of France
}

\author{
Lucien F Trueb \\ In der Oberwis 9, CH-8123 Ebmatingen, Switzerland
}

Two millennia of mining history in Salsigne, near Carcassonne in France, has recently led to a profitable gold mining operation. The geological and historical perspectives are outlined and the methods used for extraction described. This mine produced 79,286 ounces of gold in 1995/6.

Western Europe as a whole is a very minor player in the worldwide league of gold producers. Excluding Russia, the total production is of the order of 32 metric tonnes (just over 1 million ounces), the greater part being a by-product of copper, zinc, lead and nickel refining. And even the ore-concentrates smelted in the Old World are mostly imported. Only a few gold mines are presently in operation: in addition to small deposits being mined in Scandinavia, mining has started in Pahtavarra (Finland) and is being restarted at Kassandra in Greece. These newcomers still have to establish their reputation: the Salsigne ore body in France on the other hand looks back on two millennia of mining history.

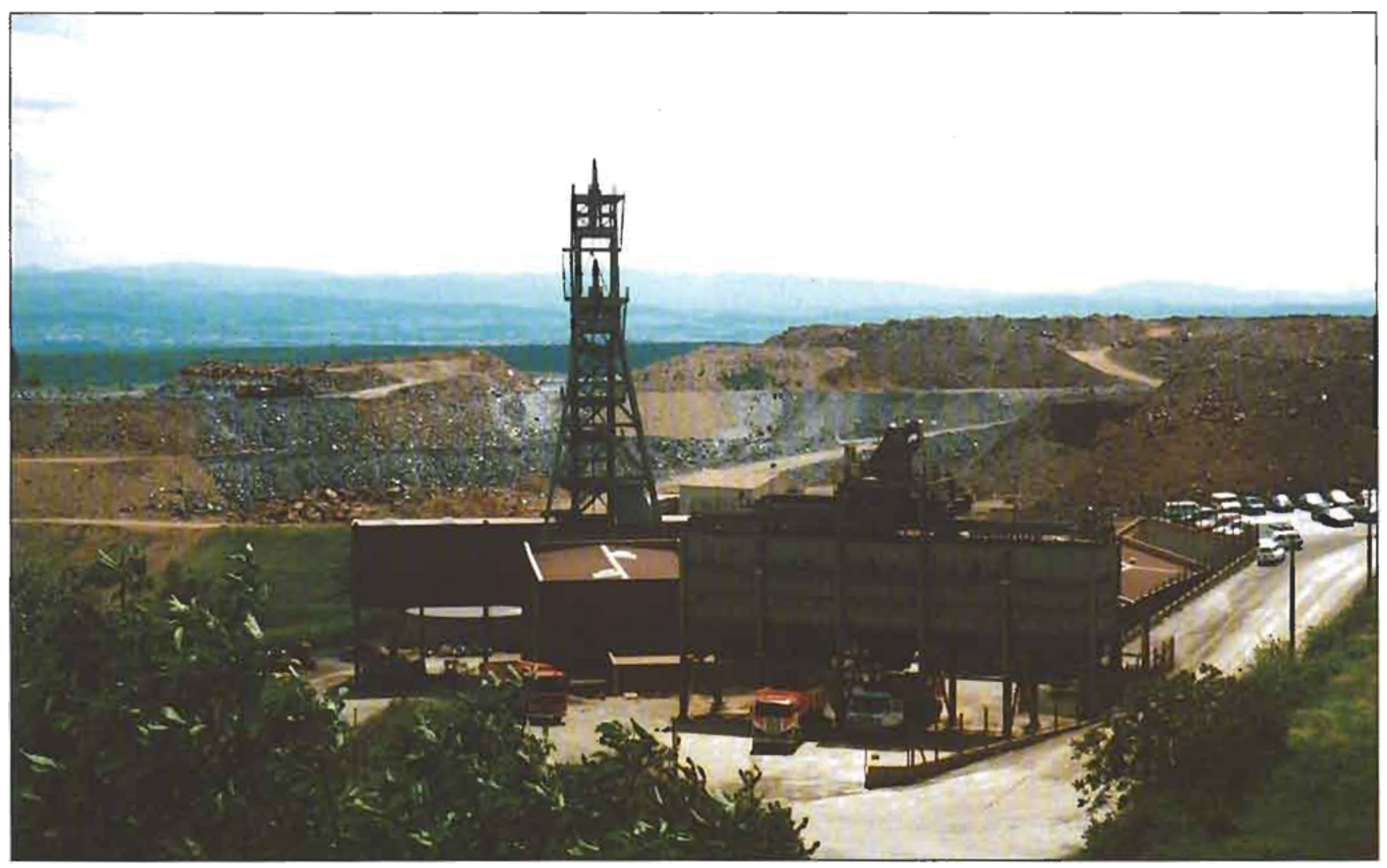

View of the Mines d'Or de Salsigne 


\section{GEOLOGICAL FEATURES OF THE SALSIGNE GOLD-BEARING FORMATIONS}

Large parts of the European continent consist of a maze of microplates, which has been subjected to three major phases or orogeny during the past 500 million years. Accordingly the geology is rather intricate nearly everywhere and that at Salsigne, a small village $13 \mathrm{~km}$ north of the walled city of Carcassonne at the extreme south-western end of the Massif Central is no exception. Moreover, Salsigne has two adjacent ore bodies which were formed as a result of the penetration of mineralizing fluids into overlying formations at different times. These ore bodies are known respectively as the 'open-pit' ore body and the ' $2 X$ ' ore body.

The open-pit ore body was apparently formed in Cambrian and Devonian metamorphosed sandstones, shales and carbonates which derive from sediments in the Tethys Sea, and which were extensively folded by uplift of the nearby Montage Noire. The latter consists of a central core of Proterozoic and Paleozoic gneisses and late Hercynian granites. The mineralizing fluids presumably had their origin in a granite intrusion which solidified $5 \mathrm{~km}$ to the west during the mid-Devonian to early Carboniferous period, 360 million years ago. The gold and associated minerals from these fluids occur in sulfide-rich veins, filling faults and fractures in sandstone and dolomitic limestone, and in flat-lying replacements of Cambrian carbonates and sandstones.

The quartz veins and veinlets contain finely disseminated arsenopyrite and pyrite, with lesser pyrrhotite and minor chalcopyrite. These were exposed at or near the surface in Roman times and had formed an oxidized zone or gossan which was mined and used for iron production by the Romans. This oxidized material and the underlying unoxidized ore are today mined by opencast methods for gold production.

The $2 \mathbf{X}$ or underground ore body was formed at a significantly later date when sulfide-laden silica-rich fluids intruded into the massive shear-zone (detachment fault) between Devonian calcschist and an underlying layer of Cambrian schist. Trace element analysis shows that these fluids also formed as a result of a granitoid intrusion during the Hercynian orogeny (380 to 290 million years ago). A totally barren calcschist overlays the $2 \mathrm{X}$ ore body and separates it from the open-pit ore bodies. In this case also the bulk of the sulfides is disseminated in quartz and the gold is associated with arsenopyrite, pyrite and local pyrrhotite.

\section{HISTORY OF EXPLOITATION OF THE SALSIGNE ORE DEPOSITS}

\author{
The Roman Era and the Middle Ages: Production \\ of Iron
}

The Romans mined the opencast ore body as a source of iron, for about 300 years, until the third century AD. With the technology at their disposal, they apparently did not discover that the siderite/ankerite gossans they mined as iron ore were weathered caps of auriferous pyrite and arsenopyrite. The Romans would have loved the gold.

During this period, smelting was carried out using charcoal and wind power. The ruins of three granite 'blast furnaces', 10-15 m high, have been found on the tops of nearby hills. Long stone walls on two sides funnelled prevailing winds blowing either from the Pyrenees mountains to the south or from the Atlantic to the north-west into the furnace mouths. In the course of time the Roman ore smelting produced 11 million tonnes of slag, containing an estimated $2.5 \mathrm{ppm}$ or 25 tonnes $(800,000 \mathrm{oz})$ of gold. It is highly unlikely that this gold will ever be recovered since the village of Les Martyrs has been built on top of the slag heaps.

Mining continued intermittently at Salsigne during the Middle Ages, and several fortified castles in the vicinity testify to the strategic importance of the site.

The Period 1873-1910: Production of Arsenopyrite

Complete records of the mine are available from 1873, when modern commercial mining operations started.

At first, the interest concentrated on the arsenopyrite: a concentrate was shipped to Wales until 1910, where it was used for the production of arsenic. Locally, the finely ground ore was dusted liberally on the vineyards for fighting fungal diseases; for this reason, the entire region has become a geochemical arsenic-anomaly. It has been estimated that Salsigne supplied $25 \%$ of the world's arsenic needs.

The Period 1892-1992: Discovery of Gold, Stimulating Expansion of Mining and Refining

Gold was discovered near Salsigne in 1892, and from the following year onwards was mined on the site of the present pit, but only in small quantities. Production of the order of $100 \mathrm{~kg}$ per year was reached in 1908. In the following decades, the Salsigne ore body was mined for pyrite and pyrrhotite, which were roasted, cyanide-treated to extract the precious metals and then shipped as iron ore to the steel industry. The 'Société Mines et Produits Chimiques de Salsigne' (SMPCS) 


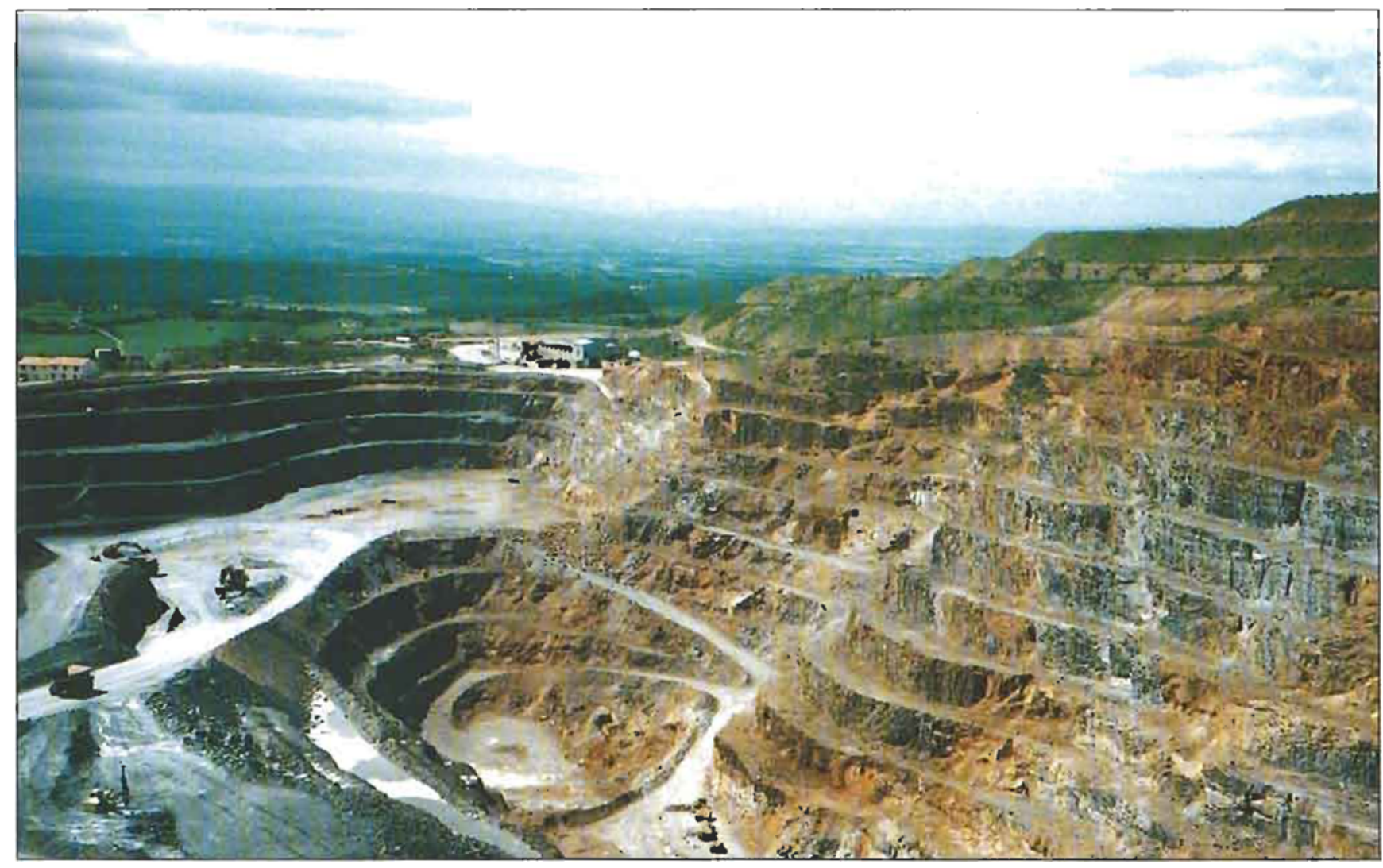

View of the Mines d'Or de Salsigne

was formed in 1924. Roasted and cyanided pyrite, as well as minor chalcopyrite, continued to be sold as iron and copper ores, and small amounts of bismuth found uses in the pharmaceutical industry. The cumulative production to date of precious metals amounts to nearly 100 tonnes of gold (3.22 million oz) and some 300 tonnes of silver. This is considerably more than the total output of any other gold mine in Western Europe.

In 1980, the French government-owned mining company 'Coframines' incorporated SMPCS into the BRGM (Bureau des Recherches Géologique et Minières) group. The major technical innovation introduced at that time was the use of sulfur dioxide produced by the roasting operations for the production of sulfuric acid. Salsigne pioneered a new version of the age-old lead chamber process, which allows the production of concentrated acid from dilute sulfur dioxide fumes.

This did not prevent the strike-plagued and technically antiquated mines from accumulating heavy losses. They were closed in 1991 and liquidated in 1992. In that same year, they were bought by two Australian companies; Eltin Minerals Pty Ltd (51\%), one of the major mining contractors 'downunder', and the gold producer Orion Resources (49\%). The present 'Mines d'Or de Salsigne' (MOS) are jointly owned by Eltin and Orion. The workforce consists of 190 persons, only two managerial jobs being held by Australians.

\section{THE PERIOD 1992 TO DATE: MODERN DEVELOPMENTS IN GOLD MINING}

Under its new ownership, both the open-cast mining and ore processing techniques have now been modernized. Like ores from similar gold deposits elsewhere, the Salsigne gold ores are refractory, and this implies that all the gold cannot be extracted from them by cyanide leaching. In other situations this problem has been overcome by first concentrating the sulfides, arsenides and associated gold by flotation and oxidizing the concentrates chemically, microbiologically, or by roasting before submitting them to cyanide extraction. All these procedures have their own advantages and disadvantages in terms of their efficiencies, the environmental problems created, and the associated capital and running costs.

The Australian companies have made Salsigne into what it should have been all along: a straight goldmine. 
The iron, copper, arsenic and bismuth minerals have very little commercial value and now all end up in the tailings pond. The effort is concentrated on mining gold-bearing sulfide ores which contain an average of $7.7 \mathrm{ppm}$ gold, $114 \mathrm{ppm}$ silver, $0.67 \%$ copper, $0.13 \%$ bismuth and $0.041 \%$ antimony as mined in the pit. The sulfide ores in the underground mine ( $2 \mathrm{X}$ ore body) contain 8.8 ppm gold, $69.2 \mathrm{ppm}$ silver, $0.15 \%$ copper, $0.22 \%$ bismuth and $13.1 \%$ arsenic. Some particularly rich zones contain ore with 15 to $20 \mathrm{ppm}$ gold. Known gold reserves are of the order of 42 tonnes (1.34 million oz).

The Salsigne ore body consists of two adjacent auriferous formations with a totally different geological and geochemical history. Both opencast and underground mining technologies are being used. The elliptical opencast mine ('la carrière' as the French call it) now measures 800 by $450 \mathrm{~m}$ : it was opened in 1983 and is being extended both to the north and south. Good ore is also available to the west, where an old underground mine has been intercepted and cleaned out. Further extension in that direction is hindered by a dump of waste rock of about 30 million tonnes.

The new ore treatment plant has a capacity of 500,000 tonnes and has been working around full capacity for the past two years. Rotary crushers reduce the particle size to $20 \mathrm{~mm}$ in three stages, the wet ball mill delivers particles under 75 micron. A sulfide concentrate is obtained after four stages of flotation with a yield of 90 to $95 \%$. The sulfide fraction has a gold content of 20 to $25 \mathrm{ppm}$; it is reground to under 38 micron and cyanidated while oxygen is blown into the slurry. Gold and part of the silver are dissolved and form cyanide complexes. Thanks to a separate cyanide leach of the flotating waste, a remarkable gold recovery of over $80 \%$ is achieved, despite the fact that the refractory sulfidic ore is neither roasted nor subjected to a bacterial treatment. As the gold particles adhere to the sulfide crystals, very fine ball milling is required in order to expose them to the cyanide solution. This process is a vast improvement on conventional roasting and leaching with sulfuric acid which achieved only $55 \%$ gold recovery.

Precious metals are extracted by means of the CCIL process (concentrate carbon in leach) with a system of nine tanks. The sulfide-slurry is oxygenated in the first tank, cyaniding begins in tank two and continues in tanks three and four. Additional cyanide and coconut-charcoal are added there. In the five last tanks, the gold and silver complexes are adsorbed by the charcoal which is moved upstream towards the more concentrated solutions. At the same time, the slurry is being depleted while moving downstream. The cyanide concentration is very low $(0.05 \%)$, and the air just above the tanks contains less than $1 \mathrm{ppm}$ of cyanide. Spent cyanide is detoxified by oxidation to cyanate, which is decomposed to ammonia and carbon dioxide.

The loaded charcoal is treated in batches of 3.5 tonnes with alkaline cyanide under pressure at a temperature of $115^{\circ} \mathrm{C}$. After being stripped of the precious metals, the charcoal is regenerated at $700^{\circ} \mathrm{C}$ and returned to the leaching circuit. Gold and silver are electroprecipitated onto steel wool cathodes. This metal is washed, dried and melted in a gas-fired furnace; the iron is reacted to slag with lime and sand at a temperature of $1100^{\circ} \mathrm{C}$.

The raw gold is cast into a cascade of iron moulds, which allows separation of the molten slag. After solidification, the slabs of raw gold (doré) with 10\% silver and 20\% copper are mechanically cleaned and stored until they can be shipped to a precious metals refiner where they are refined to fine gold and silver. During the 1994/1995 fiscal year, 78,323 ounces $(0.24$ tonnes) of gold were produced; the production increased slightly to 79,286 ounces ( 0.25 tonnes) in 1995/1996. In that same year, silver production was 45,000 ounces ( 0.14 tonnes).

\section{ACKNOWLEDGEMENTS}

The author thanks Duncan Buchanan, Chief Geologist, Mines d'Or de Salsigne (MOS) for his co-operation and provision of photographs for the Figures.

\section{ABOUT THE AUTHOR}

The author is a graduate of the Physical Chemistry Department of the Swiss Federal Institute of Technology (ETH) in Zurich, Switzerland. $\mathrm{He}$ worked as a research metallurgist both in Switzerland and in the United States. From 1972 to 1996 he was the science and technology editor of Neue Zürcher Zeitung, the leading daily newspaper in Switzerland. $\mathrm{He}$ is the author of two books ('Gold', NZZPublishing, Zurich 1992 and 'Die chemischen Elemente', Hirzel-Verlag, Stuttgart, 1996). $\mathrm{He}$ is currently active as a free-lance science writer. 